\title{
O WYBRANYCH ZAIMKACH GWAROWYCH Z POLSKI POŁUDNIOWO-WSCHODNIEJ (PRZYCZYNEK)
}

Słowa klucze: zaimki polskie, zaimki gwarowe, zaimki prasłowiańskie, gwary Polski południowo-wschodniej, interferencje leksykalne

Keywords: Polish pronouns, dialect pronouns, proto-Slavic pronouns, dialect of South-Eastern Poland, lexical interferences

Olgierd Chomiński (1915: 155-156), który przeszło sto lat temu badał polskie gwary okolic Rymanowa ${ }^{1}$, w tym język Posady Jaśliskiej, z której pochodzi większość omawianego tutaj materiału leksykalnego (jest to także wieś rodzinna autora niniejszego opracowania), zwrócił uwagę na trzy charakterystyczne dla tego obszaru językowego odrębności zaimkowe: podwojenie zaimków wskazujących ten, ta, to (w obu liczbach), zaimek przeczący 'nikt' o postaci nichto oraz zaimki nieokreślone 'ktoś', 'coś' utworzone za pomocą partykuły -si(k) lub da-. Występują na tym obszarze inne jeszcze, nieodnotowane przez O. Chomińskiego zaimki różne od ogólnopolskich lub innogwarowych. Celem niniejszego artykułu, o charakterze przyczynku, jest omówienie pochodzenia i budowy tych zaimków, ale również ich funkcji i znaczenia, jeśli są one odmienne od ogólnopolskich bądź innogwarowych ${ }^{2}$. Zaimki tego

1 Obecnie miasteczka w województwie podkarpackim, powiecie krośnieńskim.

2 Nie wdaję się tutaj w szczegółowe rozważania na temat deiktycznej/semantycznej natury zaimka, podzielam jednak stanowisko m.in. Ireny Szczepankowskiej (2012), która uznaje tę część mowy za posiadającą znaczenie. Od razu dodam też, że, podobnie jak ona, przyjmuję tu tradycyjny (tzw. szkolny) podział zaimków. 
rodzaju są wciąż żywe w gwarze, używane głównie przez przedstawicieli najstarszego i średniego pokolenia (celem artykułu nie jest jednak socjolingwistyczna charakterystyka ich żywotności).

Właściwe wywody należy poprzedzić krótką informacją na temat położenia wsi, z której pochodzą opisywane zaimki. Posada Jaśliska (wieś w województwie podkarpackim, powiecie krośnieńskim) leży w pobliżu granicy ze Słowacją, przy tzw. trakcie węgierskim, dawnym szlaku handlowym wiodącym przez tereny dzisiejszej Słowacji na Węgry33; przed II wojną światową zamieszkana była w części przez ludność rusińską (łemkowską) i sąsiadowała z osadami w całości łemkowskimi (z wyjątkiem Jaślisk, obecnie wsi, zaś w przeszłości miasteczka wyłącznie polskiego). Gwary Posady Jaśliskiej i okolic należą do gwar pogranicza wschodniego młodszego (por. Urbańczyk 1968).

\section{Zaimki osobowe w formach czasu przeszłego czasownika}

Na początku warto odnotować zjawisko nie tyle zaimkowe, deklinacyjne, ile werbalne, z zakresu fleksji czasownika, w którym jednak ważną funkcję pełnią zaimki. Idzie tutaj o analityczne konstrukcje form osobowych czasownika w czasie przeszłym, w których neutralizacji ulegają końcówki osobowe, ich funkcje zaś przejmują odpowiednie zaimki osobowe, np. Ja pojechała wczoraj do Komańczy; Byli my rano w mieście; My byli kuzyni; Ja ino swoje napisała; Gdzie ty była?. Takie formy czasu przeszłego I. Szczepankowska (2012: 281) interpretuje jako uwarunkowane historycznym rozwojem prasłowiańskich form morfologicznych czasowników; w gwarach Polski południowo-wschodniej wyjaśnia się je zazwyczaj wpływem języka ukraińskiego i jego dialektów, w tym gwar łemkowskich (por. Kurek 2009: 128-129). Tadeusz Lehr-Spławiński stwierdza co prawda występowanie takich form w zabytkach stpol. (ja miał, my wstali w Psałterzu puławskim, ja ofiarował w Biblii królowej Zofii), jednakże zastrzega, że na obszarze rdzennie polskim są one rzadkie i jedynie w Galicji Wschodniej stoją w związku z ruskim otoczeniem (Lehr-Spławiński 1914: 47), podobnie jak konstrukcje złożone używane w miejscowościach położonych wzdłuż Karpat typu dałjem, dałjeś, które „na pozór wyglądają bardzo archaicznie, w rzeczywistości jednak polegają również na wpływie otaczającej ruskiej ludności” (ibid.). Z kolei Zofia Kurzowa konstrukcje analityczne czasu przeszłego zalicza do „tych cech ukraińskich, które charakteryzowały całą polszczyznę południowo-kresową i weszły do mowy wiejskiej osadników najwcześniej, przed wszystkimi innymi, przy minimalnym oporze mówiących, ponieważ uważano je za cechy i formy polskie" (Kurzowa 2007: 98).

3 Do wybuchu II wojny światowej regularnie chodzono z Posady Jaśliskiej, a zwłaszcza z rzemieślniczych Jaślisk, na handel ze Słowakami, którzy do dziś przyjeżdżają jako goście i uczestnicy dorocznych dożynek w jaśliskiej parafii. 


\section{Zaimek przeczący nikto 'nikt'}

Olgierd Chomiński, jak wspomniałem, odnotował w swej pracy zaimek nichto 'nikt'. Współcześnie coraz częściej wymawiany jest on jako nikto, jego znaczenie jest jasne, jego budowa także nie wymaga obszernych wyjaśnień. Nikto jest najpewniej kontynuacją stanu jeszcze prasłowiańskiego: partykuła przecząca $n i+k t o$ (SEBor: 365 , por. współczesne ros. никто, błr. нiкmo, ukr. нixmo, słow. nikto, czes. nikto) - ale już nie stpol., SStp formy takiej nie notuje ${ }^{4}$ - lub też efektem wyrównania analogicznego do innych zaimków zakończonych na -o (np. wszystko, to, co, kto).

\subsection{Zaimki nieokreślone z partykułą -si(k) (ktosi, cosi; jakisi, którysi; gdziesi, kiedysi, skq̨dsi; jakosi)}

Zaimki nieokreślone w gwarze Posady Jaśliskiej budowane są według dwóch schematów, zgodnie z pierwszym tworzy się je od zaimków pytajnych za pomocą partykuły -si, wzmacnianej także partykułą - $k$. Jak wiadomo, zaimki takie występują powszechniej, głównie w gwarach Śląska i Małopolski, nielicznie także Wielkopolski (MSGP: $38,89,99,255)^{5}$. W ten sposób powstały w gwarze Posady Jaśliskiej: cosi (cosi będa robić 'pracować'; o, tam cosi chodzi, co to takie chodzi?; cosim miała stąd brać; cosi ta twoja Terenia nie dzwoni), ktosi (patrze, idzie do mnie ktosi; znowu przyjechały dwa srebne [auta] jakisie, ktosi przyjechał), (g)dziesi ${ }^{6}$ (gdziesi cosi ma tam w tym; no poszukaj, jest tam gdziesi; wróci dopiero dziesi we wtorek), skądsi (przylezie taki skądsi, i co z nim robić), kiedysi (mówi, że była kiedysi u niej; kiedysiem była u niej, zrobiła herbatę; przecież kiedysi, cosi ona gada, że...), którysi (a daj tam którysi, może być ten wielki; bo na niego poskarżył którysi), jakisi (idzie do mnie jakisi chłop; a co on dzisiaj taki jakisi); jakosi 'jakoś' (trza by to jakosi spasować; sq ludzie, co nie sprzaca, a żyja jakosik; aaa... tam gdziesi, cosi, jakosi będą robili). Są one stosunkowo dobrze zachowane w gwarach Polski południowo-wschodniej.

Zaimki z partykułą uogólniającą -si kontynuują stan prasłowiański, podczas gdy w polszczyźnie ogólnej w odpowiednich zaimkach partykuła ta uległa skróceniu o element samogłoskowy do -ś, co, jak przekonuje Władysław Cyran, „wiąże się z ogólnym zanikiem samogłosek wygłosowych w nieodmiennych wyrazach" (Cyran 1967: 22) i „tłumaczy się tendencją zanikową asemantycznych, tj. obojętnych znaczeniowo, samogłosek w wygłosie wyrazu" (Klemensiewicz, Lehr-Spławiński, Urbańczyk 1981: 72-73). W wielu wsiach Polski południowo-wschodniej zaimki te

4 Są w nim za to, obok nikt, także niktej, nikty i niktyż.

5 Bywają one dodatkowo rozbudowywane (np. cosić, cosiś, cości, cościć, cosika, cosikaj 'coś'; jakisiś, jakiści 'jakiś'), nie występują jednak na obszarze, z którego pochodzi analizowany materiał (szczegółowa ich geografia zob. MSGP: 38,88 oraz hasła cosi, cosiś, cosić, cosik, cosika, cosikaj w SGP IV: 509-512).

6 Realizowane często z redukcją nagłosowego g- (dziesi), co jest dawną tendencją gwarową (Cyran 1967: 19). 
tworzone są za pomocą podwójnej partykuły: uogólniającej -si oraz wzmacniającej -k. Zaimki typu cosik, ktosik, gdziesik, jakisik itp. nie są znane językowi ogólnopolskiemu, występują wyłącznie w gwarach, zwłaszcza zaś w gwarach południowych (Cyran 1967: 54), przy czym mają szersze występowanie, sięgają dalej na zachód, do Śląska, a nawet Wielkopolski, podczas gdy formy z -si obejmują tylko część Śląska z Małopolską lub samą Małopolskę (MSGP: 38, 89, 99, 255, por. też Cyran 1967: 51-52, 54-55 oraz hasła cosi, cosik w SGP IV: 509-511). Współtworząca je partykuła wzmacniająca $-k(<-k o)$ występuje również w staropolszczyźnie oraz gwarowych zaimkach wskazujących typu tamok, tutok, haniok, wtedyk wywodzących się, zdaniem Jana Otrębskiego (1960: 183), ze staropolskich zaimków tamoko/tamøko, tutoko/tutzko.

W funkcji zaimków nieokreślonych, zwłaszcza zaimków kiedysi, gdziesi, używane są również, podobnie jak w polszczyźnie ogólnej (współczesnej i dawnej), odpowiednie zaimki pytajne, np. jak gdzie jadę, to biore pieniądze; to przyjdź kiedy do mnie.

\subsection{Zaimki nieokreślone z partykułą da-}

Drugi sposób tworzenia zaimków nieokreślonych polega na dodaniu do zaimka pytajnego cząstki da-: daco (a potem pojadę do Komańczy, to daco kupię; wieczór przyjdziesz, daco pooglądasz; będziesz daco jadt?), dakto (czy to dakto jej dał?; myślisz, że będzie na to patrzył dakto?), dagdzie (a połóż to dagdzie i chodź), dakiedy (poszliby my dakiedy do niej), dajaki (poogladałby film dajaki), daktóry (daj tamten, no, daj daktóry). Leksem (i rdzeń) da (a także synonimiczne de - ograniczone do słowiańszczyzny północnej (SPsł III: 26$)^{8}$ ) jako różnego rodzaju partykuła, także leksem w funkcji składniowej (głównie spójnikowej), jest powszechny w całej słowiańszczyźnie (SPsł II: 323-326), jednakże w tej konkretnej funkcji wyrażania nieokreśloności zaimków (i przysłówków) obszar jego występowania jest mocno zawężony do trzech ugrupowań językowych':

- dialektów słowackich (SPsł II: 323), do dziś w literackiej odmianie słowackiego występują dačo, dakto obok niečo i čosi, niekto i ktosi; słowacczyzna nie zna zaimków niekreślonych z de-;

- dialektów ukraińskich, w tym łemkowskiego, z którym na obszarze Posady Jaśliskiej i okolic współfunkcjonowała polszczyzna (por. SPsł II: 325 oraz słowniki i słowniczki w opracowaniach poświęconych dialektowi łemkowskiemu, np. Rieger 1995, 2016; Horoszczak 2004; Duda 2011); w języku ukraińskim, także w gwarach ukraińskich, znane są zaimki i przysłówki nieokreślone z de-, które

7 Realizowane zawsze $\mathrm{z} g$ - $\mathrm{w}$ drugim członie, por. przyp. 6.

8 Różnicę da: de tłumaczy SPsł (III: 26) analogią do ča : ̌́e, ša : se.

9 Jest ponadto da łączone z zaimkami nieokreślonymi w języku bułgarskim, lecz są to - zdaje się funkcje partykuły da o odmiennej, niezależnej genezie, idzie tu bowiem o konstrukcje analityczne zaimków nieokreślonych, z partykułą w postpozycji, np. койmo u да e 'ktokolwiek', как da e 'jakkolwiek' (SPsł II: 324). 
występuje również w dialektach białoruskich i występowało w rosyjskich dawnych zaimkach dialektalnych (SPsł III: 26) - im bardziej na północ, tym mniejsza produktywność partykuły de-;

- nielicznych gwar polskich sąsiadujących z łemkowszczyzną i słowacczyzną; w tej funkcji partykuła $d a-$ obca jest staropolszczyźnie i dialektom polskim (zresztą i w innych funkcjach pojawia się raczej sporadycznie). Zaimki nieokreślone na da- są w gwarach polskich dość wyjątkowe, odosobnione. Znane są niemal wyłącznie we wsiach w przeszłości „rusińskich” lub dwuetnicznych, polsko-łemkowskich. Nie występują już jednak we wsiach nieco tylko oddalonych od zwartego obszaru łemkowszczyzny, nie są znane choćby pod Krosnem. Mają też ubogie poświadczenia w kartotece SGP, np. dla dagdzie zgromadzono ledwie cztery fiszki; dwie z nich dotyczą Poraża (wieś polska na obszarze tzw. Dolinian), przy czym na jednej dopisano ołówkiem lokalizacje: „Posada Górna, Posada Dolna, Rymanów" (osady polskie w sąsiedztwie łemkowszczyzny - dopisek odnosi się do wspomnianej we wstępie pracy O. Chomińskiego (1915)), dwie kolejne fiszki dotyczą słowackiej strony Orawy. Również daco zapisano na kilku ledwie fiszkach poświadczających obecność tego zaimka po słowackiej stronie Orawy, kilkakrotnie w Besku (duża wieś polsko-rusińska) i Porażu (wieś polska) na Podkarpaciu, raz w Jurgowie na Spiszu. W SKarł (I: 306) zanotowano tylko jeden zaimek z da-, mianowicie dakto 'ktoś' z przypiskiem ,jedyny przykład” (na fiszce w kartotece SGP odnotowano, iż pochodzi on z terenu Orawy). Obecność formacji z da- na Orawie potwierdza także słownik Józefa Kąsia (KąśSGO I: 147-149), ponadto Leszek Bednarczuk (2018: 181) stwierdza ich występowanie w Muszynie i Tyliczu; oczywiście zaimki te znane są w Posadzie Jaśliskiej i okolicznych wsiach. A zatem daco, dakto itp. znają nieliczne polskie gwary pozostające w bezpośrednim sąsiedztwie z łemkowszczyzną lub słowacczyzną.

W SGP odnotowano poświadczenia za kartoteką, warto też może zauważyć, iż zaimki na $d a$ - zapisano w słowniku rozdzielnie: $d a$ co - na wzór zapisów z kartoteki (SGP IV: 479). W pracy O. Chomińskiego (1915) oraz w KąśSGO zastosowano (słusznie) pisownię łączną.

Gwary polskie nie znają w tej funkcji de-, z wyjątkiem Pomorza, na którym tworzyło ono tylko przysłówki nieokreślone (SPsł III: 26).

Partykułę da-, de- wywodzi się z ie. dō 'do tego, tu', może od rdzenia zaimkowego de-, do- (SPsł II: 325; SPsł III: 26). Indoeuropejskie zaimkowe de- znajduje kontynuant $\mathrm{w}$ dzisiejszych polskich gdzie, indziej, ówdzie.

Można zatem $\mathrm{z}$ dużym prawdopodobieństwem twierdzić, że w gwarach polskich badanego obszaru formacje nieokreślone z $d a$ - przejęte zostały z łemkowskiego, nie bez znaczenia mogło być „wsparcie” zaimków łemkowskich przez odpowiedniki słowackie, występujące powszechnie w gwarach wschodniosłowackich, których słowniki notują: daco, dasco, dachto, dachtoryj, dakotryj, dakelo, dagdze oraz przysłówki dakus, daskelo (KS: 57; HV: 61; MSS: 26; OS: 33; ZB: 89; SS: 47-48). 
Występowanie zaimków na da- w Tyliczu i Muszynie L. Bednarczuk (2018: 181182) tłumaczy wpływem słowackim, który w przeszłości, jak stwierdza Mieczysław Małecki (1938: 25), był silniejszy, nie można jednak na tym obszarze ignorować wysoce prawdopodobnego wpływu otoczenia łemkowskiego. Nieco zagadkowe są natomiast zaimki nieokreślone z da- na Spiszu, bowiem wśród gwar wschodniosłowackich gwary spiskie (i szaryszskie, por. OS: 33) są wyjątkiem i nie znają większości zaimków na da-, co jest o tyle zaskakujące, że występują te zaimki w innych gwarach wschodniosłowackich oraz u tzw. Rusinów spiskich (HV: 61; ZB: 89; SS: 47-48); na słowackim Spiszu odnotowuje się jedynie przysłówki nieokreślone dakus 'trochę', daskelo, daskela 'kilka' (KS: 57; MSS: 26; także OS: 33). Być może zatem w odniesieniu do polskiego Spisza trzeba widzieć wpływ łemkowszczyzny, M. Małecki (1938: 11) stwierdza bowiem, że pierwsza fala kolonizacji łemkowskiej weszła także na Spisz. Przede wszystkim jednak pamiętajmy, że mamy z polskiego Spisza tylko jedno poświadczenie, najpewniej zatem zarówno na polskim Spiszu, jak i słowackim da- jest wyjątkowe. Natomiast pochodzenie da- na Orawie (powszechne) należy tłumaczyć wpływem słowackim.

Inną jeszcze sugestię niesie opracowanie Janusza Riegera (1995: 17), w którym łemkowskie daszto (w gwarach łemkowskich zaimki nieokreślone na da- występują powszechnie) zaliczone zostało do zapożyczeń z języków polskiego i słowackiego; wobec nikłych wystąpień polskich a częstszych słowackich możemy się domyślać, że idzie tu o zapożyczenie ze słowackiego właśnie. Również w ESUM (II: 7-8) wśród innych pojawiają się interpretacje tych zaimków jako słowacyzmów. Być może jednak, skoro w gwarach zachodnich Ukrainy mamy postać nie tylko zgodną ze słowacką da-, lecz również wschodniosłowiańską de-, można tu mówić o współistnieniu innowacji rodzimej. Można uogólnić, że stykając się ze sobą, słowacki i łemkowski wzajemnie umacniały zaimki nieokreślone $\mathrm{z} d a-$, jednocześnie użyczając ich nielicznym gwarom polskim.

Zaimki nieokreślone w polskiej gwarze Posady Jaśliskiej i okolic są zapożyczeniami nie leksykalnymi, lecz morfologicznymi, zapożyczenie dotyczy wyłącznie partykuły $d a-$, ponieważ łemkowskie odpowiedniki omawianych zaimków to: daszczo/daszto/daszo/dakus 'coś; dachto 'ktoś'; dagde 'gdzieś'; dakoly/dakoły 'gdzieś'; dajakyj 'jakis', por. też de(!)kotryj 'niektóry' (Rieger 1995, 2016; Horoszczak 2004; Duda 2011). Polskie daco, dakto itp. to zatem hybrydy językowe. Oczywiście także w gwarach łemkowskich pojawiają się hybrydy zaimkowe, choć wyjątkowo, np. daco obok powszechnego daszto; dakiedy/dakody obok dakoły (Rieger 1995, 2016). Dla ścisłości dodajmy również, że w niektórych gwarach łemkowskich w Polsce występują także, choć nieliczne, zaimki nieokreślone z partykułą -si(k), np. desi 'gdzieś', sztosi/sztosik 'coś, jakyjsyj 'jakisi'. Są to raczej zapożyczenia z gwar polskich niż kontynuacje stanu prasłowiańskiego.

Wypada w tym miejscu postawić pytanie o redundantny stosunek zaimków nieokreślonych typu ktosi, cosi i dakto, daco. W gwarze Posady Jaśliskiej bywają one 
używane wymiennie, ale istnieją pewne ograniczenia dystrybucyjne o charakterze semantycznym. Otóż zaimki typu cosi $(k)$, gdziesi $(k)$ mają znaczenie nieokreślone 'coś', 'gdzieś', natomiast zaimki z daco, dagdzie znaczenie 'cokolwiek', 'gdziekolwiek'.

Ciekawą cechą wyrażania zaimkowej nieokreśloności miejsca i czasu jest reduplikacja (tzw. reduplikacja składniowa (Antoniak 2005: 5)) zaimków, np. Poszłaby gdzie dagdzie ('gdzieś, gdziekolwiek'), a nie siedzi cały czas $w$ domu; Ta przyjedź do nas kiedy dakiedy ('kiedyś, kiedykolwiek'); notowałem także co daco 'coś, cokolwiek, byle co' oraz kto dakto 'ktoś, ktokolwiek, byle kto'. Jak się wydaje, reduplikacja ta jest właściwa wyłącznie gwarom południowo-wschodniej Polski. Opracowania językoznawcze notują bowiem wyrażenia podwojone z kiedy, jednak nie zawsze w znaczeniu nieokreślonym, np. Zofia Stamirowska (1969: 23) odnotowuje kiedyk niekiedy $\mathrm{z}$ okolic Biłgoraja (bez podania znaczenia); kiedy niekiedy w monografii W. Cyrana (1967: 45) definiowane jest jako 'czasami', w SJPD jako 'od czasu do czasu', zaś śrpol. kiedyż tedyż u Jana Mączyńskiego znaczy 'kiedykolwiek’. Ogólnopolskie gdzieniegdzie 'w niektórych miejscach, miejscami, tu i ówdzie' ma co prawda znaczenie nieokreśloności, jednak - jak przekonuje W. Cyran - nie jest ona przez reduplikację wzmacniana, ponieważ forma podwojona jest stosunkowo późna, „pojawia się w XVIII w., zastępując niegdzie" (ibid.: 46). Wykładnikiem nieokreśloności w (kiedy) niekiedy oraz (gdzie) niegdzie jest partykuła nie, a reduplikacja to być może przejaw chęci wyraźniejszego oddzielenia niegdzie od nigdzie, za czym przez analogię poszło kiedy niekiedy, dziś jednak raczej nieużywane (gdyż nie było opozycji niekiedy: *nikiedy), a jeśli tak, to w znaczeniu nieco innym niż 'czasami' - 'od czasu do czasu'. Za pomocą nie urobiono również nieco - pierwotnie zaimek nieokreślony o znaczeniu 'coś', obecnie przysłówek / zaimek liczebny nieokreślony o znaczeniu 'trochę'. Bywa on podwajany do postaci co nieco, reduplikacja ta jednak, jak się wydaje, nie wnosi żadnej różnicy w porównaniu z formą wyjściową, prostą (tak przynajmniej wynika $\mathrm{z}$ haseł słownikowych nieco oraz co nieco w USJP).

Odpowiedź na pytanie o funkcję reduplikacji w gwarze posadzan typu kiedy dakiedy, gdzie dagdzie (oraz co daco i kto dakto) nie jest jednoznaczna, bowiem

- „reduplikacje pełnią nie tylko różnorakie funkcje w poszczególnych językach, ale także w obrębie tego samego języka. Nierzadko zdarza się, że ten sam proces pełni pozornie przeciwstawne funkcje. [...] Zazwyczaj jednak poprzez podwojenie formy wyrazu wyjściowego, reduplikacja wskazuje na pewnego rodzaju podwojenie, dosłowne lub w przenośni” (Antoniak 2005: 14);

- na ogół zatem znaczenie reduplikacji związane jest z pojęciem mnogości i intensyfikacją (ibid.). Można twierdzić, że podwojenie kiedy dakiedy i gdzie dagdzie intensyfikuje nieokreśloność $\mathrm{w}$ ten sposób, iż do elementu znaczeniowego 'nieokreślony' dodaje element 'dowolny', 'obojętny', reduplikacje tu omawiane znaczą bowiem nie tylko 'gdzieś', 'kiedyś', 'ktoś, 'coś', lecz również 'gdziekolwiek', 'kiedykolwiek', 'ktokolwiek', 'cokolwiek'; przyjedź kiedysi nie jest w pełni równoznaczne z przyjedź kiedy dakiedy (por. ktosi $(k)$ - dakto, cosi $(k)$ - daco itp.). 


\section{Reduplikacja zaimków wskazujących (toten, tota, toto, tote, toci)}

Reduplikacja zaimków w polszczyźnie mówionej mieszkańców Posady Jaśliskiej dotyczy także powtarzalności morfemów w obrębie jednego leksemu (tzw. reduplikacja morfologiczna), czego typowym przykładem jest zaimek wskazujący toto. Dodajmy jednak, że jest to $\mathrm{w}$ istocie reduplikacja pozorna, bowiem nie mamy tu do czynienia z podwojonym zaimkiem to + to, lecz z połączeniem to partykuła + to zaimek. Leszek Bednarczuk, charakteryzując polskie gwary Podkarpacia, wymienia reduplikację jako jedną z ich cech (Bednarczuk 2018: 184, zob. też 182).

Toto znane jest również polszczyźnie ogólnej, gdzie ma znaczenie 'lekceważąco lub żartobliwie o kimś lub o czymś mało ważnym' (por. Po cholerę toto żyje? Trudno powiedzieć, czy ma szyję [...] Pachnie toto jak dno beczki, jakieś nóżki, jakieś kropeczki - ohyda [...] - z Satyry na bożą krówkę Konstantego I. Gałczyńskiego). ISJP (II: 838) określa toto jako zaimek rzeczowny, natomiast analizy Dagmary Alsztyniuk prowadzą ją do wniosku, iż toto to rzeczownik, choć nietypowy, bo nie odmienia się przez przypadki (ma homonimiczne (synkretyczne) formy M. i B.) ani przez liczbę, inaczej - rzeczownik o „wybrakowanym” paradygmacie lub tzw. rzeczownik defektywny (Alsztyniuk 2010).

Inaczej rzecz ma się z gwarowym toto (r. n. zaimka toten), który jest zaimkiem wskazującym 'to', odmieniającym się przez rodzaje, liczby i przypadki (jednak nie przez wszystkie): nie wiem, kiedy mnie przyniesie toto rozliczenie; kupiłam toten ser mały, biaty 'twaróg'; mamy nie takie jak tote, inne takie; nie pojade do Krosna, jak tu sie toto robi 'ślizgawica'; ja ide het, a tota dzwoni za mna; aha Ania, daj mi tote te, jak pojedzie Marian do Komańczy to kupi te, to ci oddam; nie trza mi totych panelów. Współcześnie jednak bardzo często, niewątpliwie pod wpływem polszczyzny ogólnej, zaimki tego typu występują w gwarze Posady Jaśliskiej w postaci krótszej, zredukowanej o partykułę to-, zwłaszcza w formach przypadków zależnych: i to w środku się wystrugiwało toto; położył ten pas i się złości, bo nierówno; miat porznięte całe te, panele; na co ci te drobne?; z tyma chłopami to męka boska.

Zaimki „podwojone” są powszechne na polskim obszarze dialektalnym, np. toten „występuje na różnych niełączących się z sobą obszarach” - w Małopolsce, na Śląsku, Mazowszu i w Wielkopolsce (na Kaszubach w postaci tuten, tutentu) (Kuziorowa 1992: 108-109). To zjawisko na tyle dla gwar charakterystyczne, że znalazło odzwierciedlenie w postaci haseł w SW (VII: 87) toten, totego; tota, totej; toto 'ten oto, ta oto, to oto'. Kontynuują one w pewnym stopniu stan staropolski, a nawet starszy. Otóż stpol. to to m.in. zaimek wskazujący oraz partykuła wzmacniająca wyraz poprzedzający, zwłaszcza zaimek, najczęściej zaś zaimek wskazujący - ten to, tę to, tym to, te to, to to itp. (SStp IX: 165-166). Reduplikacja ta znana była (i jest) innym językom słowiańskim, występuje np. we współczesnej czeszczyźnie; zresztą reduplikacje rdzeni zaimkowych to ogólnie znany fakt słowiański (Kuziorowa 1992: 110), por. czeskie toto, tento, słowackie toten, dolnołużyckie tośten, tośta, tośto, rosyjskie 
эmom, ukraińskie mom, moma, momo. A zatem używane w Polsce południowo-wschodniej reduplikacje zaimkowe to efekt ogólnosłowiańskiej innowacji zaimkowej i może należy mówić o kontynuacji przez nie stanu prasłowiańskiego, ponieważ trudne (niemożliwe?) jest ustalenie zależności interferencyjnych między trzema zespołami językowymi: polskim, słowackim i łemkowskim.

Można przypuszczać, iż to jest genetycznie tą samą partykułą, co prasłowiańskie to występujące w strukturze zaimków pytajnych kzto, čbto (por. Otrębski 1960: 191); Anna Kuziorowa przypisuje jej funkcje „zwracania uwagi” (1992: 107) oraz pozbawienia zaimka charakteru zaimka wskazującego bliższego, a nadania mu charakteru zaimka wskazującego w ogóle (ibid.: 110).

Co ważne, w staropolszczyźnie partykuła -to występowała w postpozycji, natomiast współcześnie w gwarach Polski południowej (choć nie tylko tam, bo i na sporych obszarach Wielkopolski) występuje w prepozycji, co można, jak sądzę, wyjaśnić analogią do budowy zaimków wskazujących dalszych ${ }^{10}$, których pierwszy człon zawsze jest niezmienny (tam-), drugi zaś to zaimek odmieniający się przez rodzaje, liczbę i przypadki.

\section{Zaimek wskazujący haw 'tu(taj)'}

W przeszłości dość powszechny w gwarze Posady Jaśliskiej był zaimek wskazujący haw 'tu, tutaj'; dziś należy on w zasadzie do warstwy biernej słownictwa. Jego występowanie na tym obszarze można by tłumaczyć zapożyczeniem z gwar łemkowskich, w których powszechny jest zaimek hew 'to samo co haw', gdyby nie to, że siła oddziaływania języka łemkowskiego musiałaby być nieprawdopodobnie duża, zaimek haw występuje bowiem w gwarach Polski południowej dalej na zachód i na północ, w znacznej już odległości od zwartego obszaru łemkowszczyzny.

Haw to zaimek polski o starym rodowodzie, ale w źródłach pisanych haw i pokrewne formy pojawiają się dopiero w XVI w., co A. Kuziorowa uznaje za przejaw „dojścia do głosu w dobie Odrodzenia wpływów małopolskich” (ibid.: 111), znacznych już, skoro zaimki te używane były wówczas nie tylko przez pisarzy małopolskich. Ich ogólnopolski żywot trwał jednak stosunkowo krótko, co prawda jeszcze w SL (I: 825) występuje haiw 'tu, tędy, sam' obok haiwo, hain, haino, hainu, hai, han - nie odnotowuje się jednak różnicy między formami z - $w$ (zaimki bliższe) i - $n$ (zaimki dalsze) ${ }^{11}$. Między XVI a XIX w. użycie tych zaimków zostało ograniczone stylistycznie oraz społecznie i regionalnie. O ograniczeniu stylistycznym przekonuje opatrzenie tych zaimków w SL kwalifikatorem vulgaris; natomiast ograniczenia

10 Jest to reduplikacja przez analogię do innej reduplikacji (zob. Antoniak 2005: 15).

11 Pierwsze pochodzą z wykrzyknikowego $a+$ owo 'tu', drugie z $a+$ on (SPsł I: 400-401, 411), $h$ jest pochodzenia protetycznego (Cyran 1967: 47, za Antoniną Obrębską). 
społeczno-geograficznego dowodzą: a) oznaczenie wszystkich haseł gwiazdką, która pełniła funkcję kwalifikatora normatywnego, oznaczającego słowa niemieszczące się w normie języka literackiego (w tym archaizmy), oraz b) dane kartoteki SGP, potwierdzające żywotność tych zaimków w gwarach.

Gwarowe haw W. Cyran (1967: 47) określa mianem podhalańskiego, jednak badania A. Kuziorowej (1992: 105-106) dowodzą, że haw występuje licznie w Małopolsce w ogóle (obok wariantów hawo, hawoj, hawok i rzadszych hawoli, hawolik); w części północnej Polski odpowiadają mu formy bez protezy (ajw, ajwo, ajwoj, ajwu, ajwuj 'tu', rzadziej 'tam'). Zaimki te wykazywały w gwarach różną potencję, o ile bowiem małopolskie haw (i warianty) stało się podstawą słowotwórczą dla zaimka wskazującego o znaczeniu 'ten' hawten (w opozycji do dalszego hańten 'tamten'), o tyle północnopolskie zaimki bez protetycznego $h$ - rzadko są podstawą zaimków wskazujących (ajwten 'ten' oraz ajwtoten 'ts.' ${ }^{12}$ ).

Także Franciszek Sławski (SESł I: 411) określa haw jako wyraz małopolski (zaś hań 'tam' jako śląsko-małopolski). Obszar występowania haw ustala ostatecznie SGP (IX: 629-630): występuje on głównie w całej Małopolsce południowej i we wschodniej z Lubelszczyzną, rzadziej w okolicach Sandomierza i Kielc, oraz na południowym Śląsku, ale także na Warmii i Mazurach. Można go też łączyć z występującymi w Małopolsce południowo-zachodniej oraz północnej jaw, jawok i jawtu, jewtu 'tu, tutaj' (MSGP: 90).

Biorąc pod uwagę ustalenia badaczy i mocną pozycję haw w dialektach Polski południowo-wschodniej, można założyć, że haw/hew w łemkowskim jest zapożyczeniem z polszczyzny i/lub dialektów wschodniosłowackich (w których niemal powszechnie występuje hew, por. KS: 75; HV: 78; MSS: 45; OS: 44; ZB: 110; SS: 73 ${ }^{13}$ ), tym bardziej iż z dostępnych mi słowników wynika, że występują te zaimki tylko w dialektach ukraińskich południowo-zachodnich: łemkowskich, huculskich, zakarpackich (Hrinczenko I: 262; ESUM I: 488).

\section{Zaimek (i przysłówek) het}

Leksem het, spokrewniony z haw, notowany jest przez niektóre słowniki polszczyzny ogólnej w znaczeniu 'daleko, bardzo daleko, hen' oraz 'dawno, bardzo dawno temu' (SJPD, USJP, ISJP I: 505, brak het w SWJP), w SJPD i ISJP bez kwalifikatorów, w USJP z kwalifikatorem przestarzały. Jako taki het jest przysłówkiem, który używany jest również w mowie mieszkańców Posady Jaśliskiej, lecz tylko w znaczeniu przestrzennym, nie czasowym ${ }^{14}$ (np. Widzisz, że to het tam 'daleko'). Znaczy on tyle

12 Ajwtoten stanowi „człon trójstopniowego systemu, w którym spełnia funkcję wskazywania przedmiotów najbliższych, podczas gdy ten wskazuje dalsze, tamten - najdalsze" (Kuziorowa 1992: 106).

13 W postaci heu.

14 Jednak $\mathrm{w}$ gwarach $\mathrm{w}$ ogóle występuje on także w innych znaczeniach, również $\mathrm{w}$ znaczeniu czasowym. 
co 'daleko' (o, tam het idzie, pod lasem) oraz 'precz' (idź het!). Wyraża jednak i takie znaczenia, które każą umieszczać go w klasie zaimków, znaczy bowiem także 'gdzieś', a zwłaszcza 'skądś, stąd, stamtąd', np. Idę het; Idę ja het; Ja idę het 'od niej', a tota 'ona' dzwoni za mna. W takim użyciu het to zaimek dyferencyjnie gwarowy, wyrażający znaczenie kierunkowe.

Sprawę genezy tego zaimka wyjaśnia m.in. SEBor: jest to leksem o pochodzeniu co najmniej prasłowiańskim, znany $\mathrm{w}$ tej postaci także innym językom słowiańskim, również dialektowi łemkowskiemu, i powszechny w gwarach wschodniosłowackich (por. Hrinczenko I: 280; ESUM I: 502; Oniškevič 1984: 166; KS: 74; HV: 78; MSS: 45; OS: 44; Zakrewska; Arkušin 200o: 88; SS: 72; Janów 2001: 69). Pochodzi od ps. eto 'oto' oraz 'oto tu, blisko', to zaś złożone jest z ps. partykuły e 'oto' wzmocnionej partykułą to (SEBor: 194) - tą samą, która wzmacnia reduplikowane toto.

W Polsce het w znaczeniach przestrzennych 'daleko, precz, skądś' występuje na dużym obszarze, notowane jest w zasadzie w każdym dialekcie (SGP IX: 12-13). Najbardziej charakterystyczne jest jednak het dla: Podkarpacia (okolice: Jasła, Krosna, Leska, Sanoka, ale i oddalone od łemkowszczyzny okolice: Dębicy, Kolbuszowej, Rzeszowa, Niska, Przemyśla), Małopolski środkowej, południowej i wschodniej (gwary kieleckie, sandomierskie, krakowskie, podhalańska, orawska, spiska, okolic Tarnowa, sądeckie, Lubelszczyzna), południowego Śląska i Śląska Cieszyńskiego (geografia za kartoteką SGP i SGP IX: 12-13) ${ }^{15}$. W znaczeniu kierunkowym 'skądś' het notowane jest najczęściej na Podkarpaciu i pod Tarnowem. Rysuje się zatem dość wyraźne zachowanie ps. het na południu i wschodnich obrzeżach Polski ${ }^{16}, \mathrm{w}$ widłach języków słowackiego i ukraińskiego, które to języki (i co ważniejsze - ich dialekty) również het znają, nie można zatem wykluczyć „wspierającego” wpływu tych języków na gwary polskie (het nie mają natomiast białoruski i rosyjski, z wyjątkiem dialektów dońskich i kurskich, w których sporadycznie występuje геть 1. „геть-геть далеко", 2. геть! 'precz!', zapewne pod wpływem ukraińskim (SRNG VI: 167), por. też rosyjskie dialektalne эm 'tutaj, oto tutaj', эmmo 'ts.' (ESUM I: 502)).

Jako ciekawostkę odnotujmy, że het znają też gwary dwóch polskich wsi w Rumunii - Kaczyki oraz Pojany Mikuli (Kartoteka). W przypadku tej drugiej het ma genezę najpewniej polską, bowiem zamieszkują ją potomkowie górali czadeckich (Polacy). Natomiast w przypadku Kaczyki rzecz jest nieco bardziej skomplikowana, bowiem Polaków - Małopolan spod Bochni - sprowadzono tutaj dopiero pod koniec XVIII w., osadę natomiast założyli w XV w. (i wciąż ją zamieszkiwali) potomkowie społeczności ruskiej (Polonia).

15 Podobnie rysuje się zasięg het w SKarł (II: 181).

16 Jest to obszar nieco tylko rozleglejszy niż ten wyznaczany przez izoglosę haw. 


\section{Zaimek ono w wypowiedzeniach "bezpodmiotowych"}

Kolejna (i ostatnia) innowacja zostanie tutaj jedynie zasygnalizowana, ponieważ nie odnotowałem jej w mowie mieszkańców Posady Jaśliskiej, lecz w położonej ok. $30 \mathrm{~km}$ na północny zachód Niżnej Łące i w sąsiedniej Głowience, jednak zasługuje ona również na wspomnienie.

Owa osobliwość dotyczy funkcji składniowej zaimka osobowego ono, który, prócz pełnienia tych samych funkcji co w polszczyźnie ogólnej, używany jest też w funkcji szczególnej - podmiotu w wypowiedzeniach, które w języku ogólnopolskim mają postać wypowiedzeń bezpodmiotowych, opisujących zazwyczaj zjawiska i stany atmosferyczne oraz stany i zjawiska fizyczno-psychiczne dotyczące człowieka. A zatem zdania typu: Nie bolałoby tak, jakbym ręka nie ruszała; Będzie lało; Byłoby ciepło, jakby nie wiało, w Niżnej Łące mogą mieć nieco inną postać: Ono by tak nie bolało, jakbym ręka nie ruszała; Ono będzie lało; Ono by było ciepło, jakby nie wiało; podobnie Ono jak zacznie wiać, to zakurzy ('zawieje') cała droge; rzadziej takie użycia zaimka ono występują w innego rodzaju wypowiedzeniach bezpodmiotowych (np. Ono pewnie linkę zarzuciło i zrobiło zwarcie - o linii wysokiego napięcia). Z Gramatyki historycznej języka polskiego dowiadujemy się, iż konstrukcje bezpodmiotowe są w gwarach używane „bardzo chętnie, zwłaszcza gdy chodzi o zjawiska przyrody", z drugiej jednak strony w gwarze łowickiej (i w innych gwarach, np. lasowskich) pojawia się w tego typu zdaniach „podmiot formalny, jakkolwiek treściowo również nieokreślony - zaimek ono, np. óno pada, [...] óno ma sie na dysc, [...] óno beło $w$ gazecie, óno sie zimom näjbarzy choruje" (Klemensiewicz, Lehr-Spławiński, Urbańczyk 1981: 399); konstrukcje typu ono będzie lało występują też w okolicach Przeworska. Można przypuszczać, że jest to zjawisko marginalne w polskich gwarach, SKarł ono w takiej funkcji nie odnotowuje ${ }^{17}$.

Trudno wskazać jednoznaczne i bezdyskusyjne wyjaśnienie takich konstrukcji składniowych, można wysnuć dwa przypuszczenia. Po pierwsze, unikanie wypowiedzeń bezpodmiotowych może być przejawem dążenia do konkretyzacji i porządkowania fenomenów świata empirycznego. Nawet jeśli utrudnione lub niemożliwe jest rozpoznanie wśród zjawisk atmosferycznych czy fizyczno-mentalnych wykonawcy czynności lub sprawcy stanu, to na płaszczyźnie językowej, opisującej owe stany i czynności, agens (wykonawca, sprawca) jest wyrażony formalnie, właśnie za pomocą zaimka wskazującego ono ${ }^{18}$. Po drugie zaś ${ }^{19}$, możliwa jest interpretacja związana $\mathrm{z}$ pierwszą, ale jednocześnie w pewnym sensie jej przeciwna, mianowicie ono $\mathrm{w}$ zda-

17 Można jednak oddnaleźć takie konstrukcje w kartotece SGP, np. ono bydzie padać z Kramska.

18 Na marginesie - por. np. niemieckie, angielskie lub francuskie 'on/to pada': es regnet, it's raining, il pleut.

19 Na możliwość takiej interpretacji zwróciła mi uwagę dr hab. Kinga Tutak, za co bardzo Jej w tym miejscu dziękuję. 
niach „bezpodmiotowych” może być wykładnikiem tzw. modalności epistemicznej, wyrażającej niepewność mówiących co do statusu ontologicznego bytów powodujących pewne zjawiska, głównie pogodowe. Co więcej ono w tego typu konstrukcjach składniowych występuje na ogół w znaczeniu negatywnym i w kontekstach, które przedstawiają coś niepożądanego, nieprzyjemnego (por. powyższe przykłady).

W zakresie omówionych zaimków trzy języki: polski, słowacki i dialekt łemkowski tworzyły raczej wspólnotę, nie zaś konkurencję, co nie oznacza, że relacje między nimi są łatwe do uchwycenia, przeciwnie. Zilustrujmy je już na zakończenie przykładem. W jednej z gwar wschodniosłowackich, gwarze sotackiej, nie występuje powszechny na Słowacczyźnie hew, zanotowano za to hevkac ${ }^{20}$ o znaczeniu 'szczekac' (słowackie brechat'). Można przypuszczać, że jest to czasownik oznaczający dosłownie 'mówić hew (używać obcego, niezrozumiałego słowa)', a więc mówić nieco inaczej, niezrozumiale. Do takiej interpretacji upoważnia podobne zjawisko widoczne w gwarze Jaślisk (sąsiadujących z Posadą Jaśliską), których mieszkańcy przezywają sąsiadów z Posady Jaśliskiej hauczokami. Przezwisko to oznacza 'tych, którzy mówią odmienną gwarą', a więc używają słowa haw nieobecnego w gwarze jaśliszczan (tego typu przezwiska są dla gwar bardzo charakterystyczne). Wtórnie tylko kojarzy się ono z hauczeć (mowa posadzan jest niezrozumiała, gorsza, jak ,język” psa), tym bardziej że gwary tych okolic nie znają hauczeć, szczekać (lecz - podobnie jak w słowackim i łemkowskim - brechać). Skojarzenie to wzmacniane jest niewątpliwie wymową łemkowską (dwuwargowe $\omega$ ), haw brzmi jak hau - a jest to cecha obca mowie jaśliszczan, ludności niegdyś miejskiej i w całości polskiej. Niewykluczone, że na powstanie przezwiska wpłynęło łemkowskie hawkaty 'szczekać' (synonim brechaty), pamiętajmy jednak, że samo haw w łemkowskim pochodzi prawdopodobnie z polskiego, hawkaty mogło więc mieć także znaczenie 'szczekać, czyli mówić niezrozumiale', tym bardziej że jest w nim polskie haw-, nie zaś łemkowskie hew (z kolei w słowackim czasowniku widać wpływ łemkowski, nie polski) ${ }^{21}$.

\section{Skróty}

błr. - białoruski; czes. - czeski; ie. - indoeuropejski; ps. - prasłowiański; ros. - rosyjski; słow. - słowacki; stpol. - staropolski; śrpol. - średniopolski; ukr. - ukraiński

20 Czasownik hewkać znają też gwary polskie, ściślej: lubelskie (SGP IX: 633 - jest tu również poświadczenie z konińskiego, jednak z kwalifikatorem sporad.).

21 Warto wobec powyższego zastanowić się nad tym, czy znaczenie 1. 'szczekać' jest pierwotne wobec znaczeń odnoszących się do zachowań mownych: 2. 'krzyczeć na kogoś' i 3. 'obgadywać kogoś' (SGP IX: 633), tym bardziej że SGP nie odnotowuje onomatopeicznego *haw na szczekanie psa, które mogłoby być podstawą słowotwórczą czasownika hawkać. 


\section{Literatura}

Alsztyniuk D., 2010, Składniowe i semantyczne cechy ciagu toto, „Linguistica Copernicana” 1 (3), s. 225-233, [on-line:] http://dx.doi.org/10.12775/LinCop.2010.011.

Antoniak D., 2005, Reduplikacje jako uniwersum jezykowe, „Investigationes Linguisticae” XII, s. 1-16, [on-line:] https://doi.org/10.14746/il.2005.12.2.

Arkušin G., Slovnik zahidnopolis'kih govirok, t. I-II, Luc'k 2000.

Bednarczuk L., 2018, Początki i pogranicza polszczyzny, Kraków.

Chomiński O., 1915, Djalekty polskie okolic Rymanowa, „Materiały i Prace Komisji Językowej Akademii Umiejętności w Krakowie” VII, s. 75-182 (nadbitka).

Cyran W., 1967, Przysłówki polskie. Budowa słowotwórcza, „Prace Wydziału I Językoznawstwa, Nauki o Literaturze i Filozofii ŁTN” 64, Łódź.

Duda I., 2011, Lemkivskij slovnik. 26 ooo sliv, Ternopil', [on-line:] https://lemko.org/pdf/ Duda2011.pdf.

ESUM: O. Mel'ničuk (red.), Etimologičnij slovnik ukraïns'koï movi, t. 1-6, Kï̈ 1982-2012.

HoroszczaK J., 2004, Słownik łemkowsko-polski, polsko-łemkowski, Warszawa.

Hrinczenko: B. Grinčenko (red.), Slovar' ukraïns'koï movi, t. I-IV, Kiïv 1907-1909.

HV: D. Hevery, Krátky slovník nárečia slovenského vel'korevištianskeho, Bratislava 1997.

ISJP: M. Bańko (red.), Inny słownik języka polskiego, t. I-II, Warszawa 2000.

JANów J., 2001, Słownik huculski, oprac. i przygot. do druku J. Rieger, Kraków.

Kartoteka: Kartoteka Słownika gwar polskich w Zakładzie Dialektologii Polskiej IJP PAN w Krakowie.

KąśSGO: J. Kąś, Słownik gwary orawskiej, wyd. II popr. i poszerz., t. I-II, Krakow 2011.

KlemensiewiCZ Z., LeHR-SpŁAWIŃski T., URBAŃCZYK S., 1981, Gramatyka historyczna języka polskiego, wyd. 4, Warszawa.

KS: A. Kret, Krátky slovník nárečia slovenského spišského, Bratislava 1994.

Kurek H., 2009, Polska wieś południowo-wschodniego pogranicza - trzy typy języka i kultury (na przykładzie regionu krośnieńskiego), [w:] M. Skarżyński, M. Szpiczakowska (red.), $W$ kręu języka. Materiały konferencji „Słowotwórstwo - słownictwo - polszczyzna kresowa” poświęconej pamięci Profesor Zofii Kurzowej. Kraków 16-17 maja 2008, „Biblioteka LingVariów”, t. 2, Kraków, s. 123-133.

Kurzowa Z., 2007, Dialekt południowokresowy i jego gwary ludowe, [w:] eadem, Prace językoznawcze, t. 3: Ze studiów nad polszczyzna kresowa. Wybór prac, red. M. Skarżyński, M. Szpiczakowska, Kraków, s. 94-101.

Kuziorowa A., 1992, Gwarowe odpowiedniki zaimków ten, tamten, [w:] M. Kucała, J. Reichan (red.), Studia historycznojęzykowe i dialektologiczne, „Prace Instytutu Języka Polskiego PAN", nr 78, s. 105-112.

Lehr-SpŁawiński T., 1914, O mowie Polaków w Galicji wschodniej, „Język Polski” II, s. 40-51. MaŁecki M., 1938, Język polski na południe od Karpat (Spisz, Orawa, Czadeckie, wyspy językowe) z 2 mapami, „Biblioteczka Towarzystwa Miłośników Języka Polskiego”, nr 12, Kraków.

MSGP: J. Wronicz (red.), Mały słownik gwar polskich, Kraków 2010.

MSS: J. Hodorovský, Malý spišský slovník, Spišská Nová Ves 1997.

ONIŠKevič M., 1984, Slovnik bojkivs'kih govirok, t. 1-2, Kiïv.

OS: M. Zimkova, Krátky slovník nárečia slovenského okružniansko-šarišského, Bratislava 1997. 
Otręвski J., 1960, Die slawischen k- und t- Partikeln, „Lingua Posnaniensis” VIII, s. 183-193. PolACY: http://bukowinski.net/polacynabukowinie/.

Polonia: https://sites.google.com/site/poloniawrumunii/o-nas.

RIEGER J., 1995, Stownictwo i nazewnictwo łemkowskie, Warszawa.

Rieger J., 2016, Mały słownik łemkowskiej wsi Bartne, Warszawa.

SEBor: W. Boryś, Słownik etymologiczny języka polskiego, Kraków 2005.

SESŁ: F. Sławski, Słownik etymologiczny języka polskiego, t. I-V, Kraków 1952-1982.

SGP: Słownik gwar polskich, red. M. Karaś (Źródła, t. 1), J. Reichan (t. 2-9, z. 2), S. Urbańczyk (t. 2-5), J. Okoniowa (t. 6-9, z. 2), B. Grabka (t. 7-9, z. 2), R. Kucharzyk (t. 9, z. 2-t. 10, z. 2), t. 1-3: Wrocław - Warszawa - Kraków 1977-1991, t. 4-10: Kraków 1992-2019.

SJPD: W. Doroszewski (red.), Słownik języka polskiego, t. I-XI, Warszawa 1958-1969, [on-line:] http://www.doroszewski.pwn.pl/.

SKarŁ: J. Karłowicz, Słownik gwar polskich, t. I-VI (t. IV-VI do druku przygot. J. Łoś), Kraków 1900-1911.

SL: S.B. Linde, Słownik języka polskiego, t. I-VI, Warszawa 1807-1814.

SPsŁ: F. Sławski (red.), Słownik prasłowiański, t. I-VIII, Wrocław - Warszawa - Kraków Gdańsk 1974-2001.

SRNG: F. Filin (red.), Slovar' russkih narodnyh govorov, Leningrad - Moskva 1965-.

SS: J. Gerbóc, Krátky slovník nárečia slovenského sotáckeho zo Sniny, Bratislava 2000.

SSTP: S. Urbańczyk (red.), Słownik staropolski, t. I-XI, Kraków 1953-2002.

Stamirowska Z., 1969, Studia nad polskimi przysłówkami. Gwarowe kiedy, wtedy, nigdy, zawsze, zaraz, teraz na tle historycznym, Wrocław.

SW: J. Karłowicz, A.A. Kryński, W. Niedźwiedzki (red.), Słownik języka polskiego, t. I-VIII, Warszawa 1900-1927.

SWJP: B. Dunaj (red.), Słownik współczesnego języka polskiego, Warszawa 1996.

Szczepankowska I., 2012, O semantyce zaimków, „Białostockie Archiwum Językowe” nr 12, s. 275-291, [on-line:] https://repozytorium.uwb.edu.pl/jspui/bitstream/11320/1055/1/BAJ _12_Szczepankowska.pdf.

URBAŃCZYK S., 1968, Zarys dialektologii polskiej, wyd. 3, Warszawa.

USJP: S. Dubisz (red.), Uniwersalny słownik języka polskiego, t. I-IV, Warszawa 2003 (CD-ROM).

ZAKREwSKA: Â. Zakrevs'ka (red.), Gucul's'ki govirki. Korotkij slovnik, L'vìv 1997.

ZB: J. Bilčíkova, Krátky slovník nárečia slovenského zemplínskeho z Budkoviec, Bratislava 1998.

\section{Selected Dialectal Pronouns from South-Eastern Poland (Outline) Summary}

The author of this article discusses the structure, origin and functions of dialectal pronouns which occur in the local dialect of Posada Jaśliska near Krosno. Posada Jaśliska is a village of three cultures: Polish, Lemko and Slovakian. The author describes mutual influences of these three languages on shaping the collection of pronouns, with particular emphasis on the pronouns that are typical of this area or known only in this place: definite ones, such as haw 'here' and het 'very far, somewhere, from somewhere, away', and indefinite pronouns, such as dakto 'whoever', dagdzie 'wherever'. 